\title{
Deoxyribonucleic Acid Homologies and Ribosomal Ribonucleic Acid Similarities Among Sporeforming Members of the Order Actinomycetales
}

\author{
ERKO STACKEBRANDT, BARBARA WUNNER-FÜSSL, VALERIE J. FOWLER, AND \\ KARL-HEINZ SCHLEIFER \\ Lehrstuhl für Mikrobiologie, Technische Universität München, 8000 München 2, Federal Republic of \\ Germany
}

\begin{abstract}
We investigated the relatedness of 24 named species belonging to 18 sporeforming genera of the order Actinomycetales with respect to deoxyribonucleic aciddeoxyribonucleic acid homology and ribosomal ribonucleic acid cistron similarity. A total of 21 of these species grouped in three deoxyribonucleic acid homology clusters in which the homology values ranged between 20 and $45 \%$. The first cluster contained Actinoplanes, Ampullariella, Amorphosporangium, Micromonospora, and Dactylosporangium; the second cluster contained Streptosporangium, Planomonospora, and Planobispora; and the third cluster included Streptomyces, Chainia, Kitasatoa, Streptoverticillium, Microellobosporia, Ely. trosporangium, and Actinosporangium. The close molecular genetic relationship of the organisms in each cluster was supported by several physiological and biochemical properties of taxonomic value. The ribosomal ribonucleic acid cistron similarity data did not indicate that any two of these clusters were specifically related to each other. Microtetraspora viridis DSM 43175, Spirillospora albida DSM 43034, and Actinomadura madurae DSM 43067 grouped separately from all of the the other organisms investigated.
\end{abstract}

During the last 15 years there has been increasing interest in the phylogeny of the sporeforming members of the order Actinomycetales and in their relationship to nonsporeforming, gram-positive organisms with similar guanineplus-cytosine $(\mathrm{G}+\mathrm{C})$ contents in their deoxyribonucleic acids (DNAs). However, the classification of families and genera presented in Bergey's Manual of Determinative Bacteriology, 8 th ed. (17), is still unsatisfactory; these taxa were established mainly on the basis of features that were known to be of little value in the elucidation of the natural relationships among organisms (i.e., motility of spores, presence or absence of aerial mycelia and sporangia, and shape of sporangia). Most of the studies on the genetic relationships of these organisms have been performed by using DNA-DNA reassociation techniques $(1,11,30,33,51)$, approaches that yield rough quantitative expressions of the overall genetic sequence homologies among organisms. Since these methods can detect only the closest genealogical relationships, they are of limited value in determining the relationships of more distantly related species and of genera and families. Most studies have included species of Streptomyces only $(30,33,51)$, which is quite understandable from a commercial point of view; species of other genera have been neglected al- most completely. The most detailed study published so far (11) included 17 species belonging to 12 genera and revealed that some of the genera appeared to be as closely related as the species of one genus.

After the conserved character of the nucleotide sequences of ribosomal nucleic acids was detected $(9,10,31)$, reassociation experiments in which ribosomal ribonucleic acids (rRNA's) and rRNA cistrons were used were introduced in taxonomic studies $(31,34,35)$. However, in contrast to the large number of gram-negative organisms investigated $(5,7,8,16,18,36)$, only a few gram-positive organisms have been studied $(12,19,21,29,32)$, and there has been only one publication (32) dealing with sporeforming members of the order Actinomycetales.

In a third method which is of great value for measuring phylogenetic distances, the ribonuclease $T_{1}$-resistant oligonucleotides of $16 \mathrm{~S}$ rRNA's are compared. The similarity coefficients obtained from binary comparisons of oligonucleotide catalogs $\left(\mathrm{S}_{\mathrm{AB}}\right.$ values) have been used successfully to generate a phylogenetic tree of the bacterial kingdom (13).

The phylogenetic positions of four sporeforming members of the Actinomycetales (namely, Dactylosporangium aurantiacum, Actinoplanes philippinensis, Ampullariella regularis, 
and Streptomyces griseus) and various coryneforms, mycobacteria, and nocardiae have been described previously $(13,48,49$; E. Stackebrandt, W. Ludwig, K. H. Schleifer, and H. J. Gross, J. Mol. Evol., in press). These data have revealed that the sporeformers do not group separately from the nonsporeforming members of the Actinomycetales but are closely related to them.

To broaden the base of these studies, we investigated various representatives of the families Actinoplanaceae, Streptomycetaceae, and $\mathrm{Mi}$ cromonosporaceae by the three approaches mentioned above. In this report we present data obtained from DNA-DNA and DNA-rRNA reassociation experiments. The phylogenetic positions of various sporeforming members of the Actinomycetales (gram-positive organisms with high $\mathrm{G}+\mathrm{C}$ contents in their DNAs) as determined by a comparative analysis of their $16 \mathrm{~S}$ rRNA's will be described elsewhere.

\section{MATERIALS AND METHODS}

Bacterial strains and culture conditions. All of the organisms investigated were obtained from the German Collection of Microorganisms (DSM) (Table 1). Ampullariella campanulata DSM 43148, Ampullariella digitata DSM 43149, and Ampullariella lobata DSM 43150 were grown in brain heart infusion medium (Difco Laboratories, Detroit, Mich.). All other organisms were grown in a broth containing $1 \%$ sucrose, $0.2 \%$ yeast extract, $0.5 \%$ peptone, $0.2 \% \mathrm{KNO}_{3}$, $0.1 \% \mathrm{~K}_{2} \mathrm{HPO}_{4}, 0.05 \% \mathrm{MgSO}_{4} \cdot 7 \mathrm{H}_{2} \mathrm{O}, 0.05 \% \mathrm{KCl}$, and $0.001 \% \mathrm{FeSO}_{4}$. After sterilization, this medium was allowed to cool slowly. All strains were grown aerobically at $30^{\circ} \mathrm{C}$. For the isolation of high-molecularweight DNA, mass cultures were obtained from a total of 6 liters of medium from four 5-liter Erlenmeyer flasks, each containing 1.5 liters of medium. For the isolation of labeled DNA, cells were grown in $100-\mathrm{ml}$ portions of medium in 500 -ml flasks; the organic components of the medium used were reduced to one-half the concentrations listed for the above-described medium. To label RNA, the reduced medium was used, but yeast extract was omitted. To label DNA and RNA, $0.75 \mathrm{mCi}$ of $\left[{ }^{3} \mathrm{H}\right]$ thymidine and $0.5 \mathrm{mCi}$ of $\left[{ }^{3} \mathrm{H}\right]$ uracil, respectively, were added to the medium. Cells were harvested after 2 to 4 days. Labeled strains were harvested when the uptake of isotopes by the cells reached a maximum. The cells were harvested by filtering the broth through Whatman no. 1 filter paper. The purity of each preparation was checked microscopically.

The presence of LL-diaminopimelic acid or mesodiaminopimelic acid in cell walls was determined by the method of Rhuland et al. (39). Cell walls were prepared and hydrolyzed as described previously (41).

Isolation of nucleic acids. To isolate high-molecular-weight DNA, $30 \mathrm{~g}$ of precooled cells was suspended in $10 \mathrm{ml}$ of a $1 \mathrm{M} \mathrm{NaCl}$ solution containing 1 $\mathrm{mg}$ of proteinase $\mathrm{K}$ (Boehringer Mannheim Corp., New York, N.Y.) and $1 \mathrm{ml}$ of a $25 \%$ sodium dodecyl sulfate solution. To isolate labeled DNA, $5 \mathrm{~g}$ of precooled cells was suspended in $2 \mathrm{ml}$ of the same solution. Cells were broken by passing $5-\mathrm{ml}$ quantities of the cell suspension through a French pressure cell at 8,000 $\mathrm{lb} / \mathrm{in}^{2}$. The lysate was collected in $100 \mathrm{ml}(10 \mathrm{ml}$ for labeled cells) of $1 \mathrm{M} \mathrm{NaCl}$ and was then heated to $60^{\circ} \mathrm{C}$. After $9 \mathrm{ml}$ ( $1 \mathrm{ml}$ for labeled cells) of $25 \%$ sodium dodecyl sulfate was added the lysate was incubated for $10 \mathrm{~min}$ at $60^{\circ} \mathrm{C}$. The procedures used for the isolation and purification of both kinds of DNA have been described previously (28).

Labeled RNA was isolated from cells suspended in $1 \mathrm{ml}$ of a buffer containing $2 \mathrm{mM}$ tris(hydroxymethyl)aminomethane, $1 \mathrm{mM}$ magnesium acetate $4 \mathrm{H}_{2} \mathrm{O}, 6 \mathrm{mM} \mathrm{KCl}, 100 \mu \mathrm{g}$ of proteinase $\mathrm{K}$ per $\mathrm{ml}$, and $1 \mathrm{mg}$ of Macaloid (an anionic silica clay used for the inhibition of nucleases; Baroid Div., National Lead Co., Houston, Tex.) per ml. Breaking of the cells by a French press, phenolization of the lysate, and separation of the $16 \mathrm{~S}$ and $23 \mathrm{~S}$ rRNA's by one-dimensional sodium dodecyl sulfate-polyacrylamide slab gel electrophoresis were performed by procedures described elsewhere (Stackebrandt et al., in press). After electrophoresis, the RNA was localized by ultraviolet light. Nucleic acids appeared as dark bands after the gel was placed on a thin-layer plate containing a fluorescent indicator $(254 \mathrm{~nm})$. The $\mathrm{RNA}$-containing gel material was cut out and embedded in agarose (Bio-Rad Laboratories, Richmond, Calif.) $(0.5 \%$ in $0.1 \mathrm{M}$ ammonium formate) in a plastic tube (13 by $1.5 \mathrm{~cm}$ ) for electrophoretic elution. Electrophoreses were carried out at $45 \mathrm{~mA} /$ tube for 5 and $12 \mathrm{~h}$ for the isolation of $16 \mathrm{~S}$ and 23S rRNA's, respectively. The final steps in the isolation procedure included purification of eluted RNA from a cellulose CF 11 (Whatman) column (14) with $1 \mathrm{M} \mathrm{NaCl}$. The RNA was precipitated with 2 volumes of ethanol and was collected by centrifugation. The yields of nucleic acids were determined spectrophotometrically at $260 \mathrm{~nm}$. The specific activities of $\left[{ }^{3} \mathrm{H}\right]$ DNA ranged from $9.6 \times 10^{3}$ to $1.25 \times 10^{5} \mathrm{cpm} / \mu \mathrm{g}$ of DNA, and those of $\left.{ }^{3} \mathrm{H}\right] \mathrm{RNA}$ ranged from $3.5 \times 10^{4}$ to $6.3 \times 10^{4} \mathrm{cpm} / \mu \mathrm{g}$ of RNA.

Nucleic acid reassociation procedures. DNADNA homology studies were performed by using the membrane filter technique $(6,15,27)$. Preparation of DNA-containing filters (diameter, $5.5 \mathrm{~mm}$ ), denaturation of the DNA by alkali, and fragmentation of $\left[{ }^{3} \mathrm{H}\right] \mathrm{DNA}$ were performed by the methods of Meyer and Schleifer (28). Each hybridization was carried out with $0.1 \mu \mathrm{g}$ of fragmented $\left[{ }^{3} \mathrm{H}\right] \mathrm{DNA}$ in $200 \mu \mathrm{l}$ of $3 \times$ SSC ( $1 \times \mathrm{SSC}$ is $0.15 \mathrm{M} \mathrm{NaCl}$ plus $0.015 \mathrm{M}$ trisodium citrate, $\mathrm{pH}$. 7.0) containing $35 \%$ formamide against filter-bound DNA for $24 \mathrm{~h}$ at $60^{\circ} \mathrm{C}$. Between 7 and 10 $\mu \mathrm{g}$ of DNA was bound to each filter, depending on the strain. The amount of filter-bound DNA was determined as described by Burton (2).

DNA-rRNA reassociations were performed by the method of De Ley and De Smedt (4), with the following modifications. The experiments were done simultaneously with four filters. Each filter contained 7 to $10 \mu \mathrm{g}$ of DNA, depending on the strain, and was incubated with $0.5 \mu \mathrm{g}$ of $\left[{ }^{3} \mathrm{H}\right] \mathrm{rRNA}$ in $200 \mu \mathrm{l}$ of $5 \times \mathrm{SSC}$ containing $25 \%$ formamide for $18 \mathrm{~h}$ at $60^{\circ} \mathrm{C}$. A separate vial was used for each filter. After hybridization, the RNA-containing solution was pipetted off, and the 
TABLE 1. DNA relatedness among various sporeforming members of the Actinomycetales

\begin{tabular}{|c|c|c|c|c|c|c|c|c|c|}
\hline \multirow[b]{2}{*}{$\begin{array}{c}\text { Source of unlabeled } \\
\text { DNA }\end{array}$} & \multicolumn{8}{|c|}{ Reassociation values $(\%)$ with the following sources of labeled DNA } & \multirow[b]{2}{*}{$\begin{array}{l}\text { DNA ho- } \\
\text { mology } \\
\text { cluster }\end{array}$} \\
\hline & $\begin{array}{c}\text { Actino- } \\
\text { planes } \\
\text { philippi- } \\
\text { nensis } \\
\text { DSM } \\
43019\end{array}$ & $\begin{array}{c}\text { Actino- } \\
\text { planes it- } \\
\text { alicus } \\
\text { DSM } \\
43146\end{array}$ & $\begin{array}{c}\text { Ampul. } \\
\text { lariella } \\
\text { regularis } \\
\text { DSM } \\
43151\end{array}$ & $\begin{array}{c}\text { Micro- } \\
\text { mono- } \\
\text { spora } \\
\text { echino- } \\
\text { spora } \\
\text { DSM } \\
43141\end{array}$ & $\begin{array}{c}\text { Strepto- } \\
\text { sporan- } \\
\text { gium ro- } \\
\text { seum } \\
\text { DSM } \\
43021\end{array}$ & $\begin{array}{l}\text { Plano- } \\
\text { mono- } \\
\text { spora } \\
\text { pa- } \\
\text { ronto- } \\
\text { spora } \\
\text { DSM } \\
43177\end{array}$ & $\begin{array}{c}\text { Chainia } \\
\text { antibi- } \\
\text { otica } \\
\text { DSM } \\
43032\end{array}$ & $\begin{array}{l}\text { Kitasa- } \\
\quad \text { toa } \\
\text { kauaien- } \\
\text { sis DSM } \\
43360\end{array}$ & \\
\hline $\begin{array}{l}\text { Actinoplanes } \\
\text { philippinensis } \\
\text { DSM } 43019\end{array}$ & 100 & 36 & 27 & 19 & 10 & 6 & 10 & 8 & I \\
\hline $\begin{array}{l}\text { Actinoplanes } \\
\quad \text { missouriensis } \\
\quad \text { DSM } 43046\end{array}$ & 29 & 34 & 37 & 21 & 9 & 6 & 10 & 11 & I \\
\hline $\begin{array}{l}\text { Actinoplanes } \\
\quad \text { utahensis DSM } \\
43147\end{array}$ & 46 & 31 & 31 & 18 & 14 & 5 & 12 & 10 & I \\
\hline $\begin{array}{l}\text { Actinoplanes } \\
\text { italicus DSM } \\
43146\end{array}$ & 42 & 100 & 27 & 18 & 11 & 7 & 13 & 10 & I \\
\hline $\begin{array}{l}\text { Ampullariella } \\
\text { regularis DSM } \\
43151\end{array}$ & 28 & 23 & 100 & 23 & 10 & 6 & 11 & 10 & I \\
\hline $\begin{array}{l}\text { Ampullariella } \\
\text { lobata DSM } \\
43150\end{array}$ & 38 & 31 & 49 & 23 & 14 & 5 & 11 & 10 & I \\
\hline $\begin{array}{l}\text { Ampullariella } \\
\quad \text { digitata DSM } \\
43149\end{array}$ & 42 & 35 & 41 & 29 & 6 & 5 & 12 & 10 & I \\
\hline $\begin{array}{l}\text { Ampullariella } \\
\text { campanulata } \\
\text { DSM } 43148\end{array}$ & 36 & 35 & 42 & 20 & 13 & 4 & 11 & 11 & I \\
\hline $\begin{array}{l}\text { Amorphosporan- } \\
\text { gium aurantico- } \\
\text { lor DSM } 43031\end{array}$ & 25 & 23 & 23 & 19 & 8 & 7 & 8 & 8 & I \\
\hline $\begin{array}{l}\text { Micromonospora } \\
\text { echinospora } \\
\text { DSM } 43141\end{array}$ & 18 & 18 & 19 & 100 & 13 & 8 & 12 & 12 & I \\
\hline $\begin{array}{l}\text { Dactylosporangium } \\
\text { aurantiacum } \\
\text { DSM } 43157\end{array}$ & 19 & 19 & 20 & 24 & 11 & 10 & 13 & 7 & I \\
\hline $\begin{array}{l}\text { Streptosporangium } \\
\text { roseum DSM } \\
43021\end{array}$ & 12 & 10 & 12 & 11 & 100 & 31 & 11 & 10 & II \\
\hline $\begin{array}{l}\text { Planomonospora } \\
\text { parontospora } \\
\text { DSM } 43177\end{array}$ & 8 & 11 & 10 & 11 & 33 & 100 & 33 & 12 & II \\
\hline $\begin{array}{l}\text { Planobispora } \\
\text { longispora DSM } \\
43041\end{array}$ & 6 & 5 & 7 & 5 & 38 & 33 & 10 & 12 & II \\
\hline $\begin{array}{l}\text { Streptomyces } \\
\quad \text { griseus DSM } \\
\quad 40236\end{array}$ & 7 & 6 & 7 & 8 & 8 & 5 & 26 & 31 & III \\
\hline $\begin{array}{l}\text { Chainia antibiotica } \\
\text { DSM } 43032\end{array}$ & 11 & 9 & 12 & 10 & 8 & 6 & 100 & 32 & III \\
\hline $\begin{array}{l}\text { Kitasatoa } \\
\quad \text { kauaiensis DSM } \\
43360\end{array}$ & 6 & 6 & 8 & 7 & 12 & 5 & 40 & 100 & III \\
\hline $\begin{array}{l}\text { Microellobosporia } \\
\text { cinerea DSM } \\
43033\end{array}$ & 6 & 5 & 7 & 6 & 10 & 5 & 36 & 28 & III \\
\hline
\end{tabular}


TABLE 1-Continued

\begin{tabular}{|c|c|c|c|c|c|c|c|c|c|}
\hline \multirow[b]{2}{*}{$\begin{array}{c}\text { Source of unlabeled } \\
\text { DNA }\end{array}$} & \multicolumn{8}{|c|}{ Reassociation values $(\%)$ with the following sources of labeled DNA } & \multirow[b]{2}{*}{$\begin{array}{l}\text { DNA ho- } \\
\text { mology } \\
\text { cluster }\end{array}$} \\
\hline & $\begin{array}{c}\text { Actino- } \\
\text { planes } \\
\text { philippi- } \\
\text { nensis } \\
\text { DSM } \\
43019\end{array}$ & $\begin{array}{l}\text { Actino- } \\
\text { planes it- } \\
\text { alicus } \\
\text { DSM } \\
43146\end{array}$ & $\begin{array}{l}\text { Ampul }- \\
\text { lariella } \\
\text { regularis } \\
\text { DSM } \\
43151\end{array}$ & $\begin{array}{c}\text { Micro- } \\
\text { mono- } \\
\text { spora } \\
\text { echino- } \\
\text { spora } \\
\text { DSM } \\
43141\end{array}$ & $\begin{array}{c}\text { Strepto- } \\
\text { sporan- } \\
\text { gium ro- } \\
\text { seum } \\
\text { DSM } \\
43021\end{array}$ & $\begin{array}{c}\text { Plano- } \\
\text { mono- } \\
\text { spora } \\
\text { pa- } \\
\text { ronto- } \\
\text { spora } \\
\text { DSM } \\
43177\end{array}$ & $\begin{array}{c}\text { Chainia } \\
\text { antibi- } \\
\text { otica } \\
\text { DSM } \\
43032\end{array}$ & $\begin{array}{l}\text { Kitasa- } \\
\text { toa } \\
\text { kauaien. } \\
\text { sis DSM } \\
43360\end{array}$ & \\
\hline $\begin{array}{l}\text { Streptoverticillium } \\
\text { baldaccii DSM } \\
40845\end{array}$ & 7 & 5 & 7 & 8 & 9 & 5 & 37 & 31 & III \\
\hline $\begin{array}{l}\text { Elytrosporangium } \\
\text { brasiliense DSM } \\
43159\end{array}$ & 6 & 6 & 9 & 8 & 10 & 7 & 34 & 28 & III \\
\hline $\begin{array}{l}\text { Actinosporangium } \\
\text { violaceum DSM } \\
43350\end{array}$ & 8 & 9 & 7 & 8 & 7 & 8 & 35 & 41 & III \\
\hline $\begin{array}{l}\text { Streptomyces } \\
\text { species }^{a}\end{array}$ & 12 & 12 & 12 & 11 & 9 & 6 & 23 & 27 & III \\
\hline $\begin{array}{l}\text { Spirillospora } \\
\quad \text { albida DSM } \\
\mathbf{4 3 0 3 4}\end{array}$ & 12 & 11 & 12 & 11 & 11 & 12 & 12 & 11 & \\
\hline $\begin{array}{l}\text { Microtetraspora } \\
\text { viridis DSM } \\
43175\end{array}$ & 6 & 10 & 7 & 10 & 12 & 10 & 13 & 11 & \\
\hline $\begin{array}{l}\text { Actinomadura } \\
\text { madurae DSM } \\
43067\end{array}$ & 6 & 6 & 9 & 7 & 12 & 6 & 12 & 11 & \\
\hline $\begin{array}{l}\text { "Micrococcus } \\
\text { conglomeratus" } \\
\text { CCM } 2134^{b}\end{array}$ & 5 & 6 & 4 & 5 & 6 & 4 & 6 & 2 & \\
\hline
\end{tabular}

a The Streptomyces species was received as Actinoplanes armeniacus DSM 43125. As with all members of DNA homology cluster III, this strain contained LL-diaminopimelic acid in its cell walls.

${ }^{b}$ This name is not on the Approved Lists of Bacterial Names (43) and has not been validly published since I January 1980; hence it is without standing in nomenclature. CCM, Czechoslovak Collection of Microorganisms, Brno, Czechoslovakia.

filters were washed once with cold $5 \times \mathrm{SSC}$ and incubated with $1 \mathrm{ml}$ of a ribonuclease solution $(2.5 \mu \mathrm{g}$ of ribonuclease A [Serva, Heidelberg, Germany] and 50 $\mathrm{U}$ of ribonuclease $\mathrm{T}_{1}$ [Calbiochem, La Jolla, Calif.]) for $45 \mathrm{~min}$ at $37^{\circ} \mathrm{C}$. Then the filters were incubated in $1 \mathrm{ml}$ of $5 \times \mathrm{SSC}$ containing $25 \%$ formamide for $10 \mathrm{~min}$ at $60^{\circ} \mathrm{C}$, washed twice with $5 \times \mathrm{SSC}$, and dried in a desiccator for $2 \mathrm{~h}$ at $50^{\circ} \mathrm{C}$. After the bound radioactivity was measured, the filters were washed with toluene and dried. To determine of melting points $\left[T_{m(e)}\right]$ of the hybrids, three of the filters used in one reassociation experiment were placed in one vial containing 1 $\mathrm{ml}$ of $1.5 \times \mathrm{SSC}-20 \%$ formamide. The thermal stability of the duplexes was determined between 60 and $95^{\circ} \mathrm{C}$ by using previously described methods (4). One filter was used to determine the amount of DNA; this value was needed to calculate the amount of rRNA binding to $100 \mu \mathrm{g}$ of DNA (percent rRNA binding).

\section{RESULTS}

DNA-DNA reassociation studies. The conditions used in the DNA-DNA reassociation studies $\left(25^{\circ} \mathrm{C}\right.$ below $T_{m}$ at $\left.60^{\circ} \mathrm{C}\right)$ were identical to those reported previously in taxonomic studies on gram-positive organisms having high $\mathrm{G}+\mathrm{C}$ contents in their DNAs (i.e., on members of Arthrobacter and Brevibacterium [12, 44], Cellulomonas [46], and Oerskovia [45]). The $T_{m}$ was calculated on the basis of an average $\mathrm{G}+\mathrm{C}$ content of $72 \mathrm{~mol} \%(3,17)$. Table 1 summarizes the reassociation values for 24 sporeforming species belonging to 18 genera of Actinomycetales, as listed in Bergey's Manual (17). The average binding efficiency in the homologous system was $32 \%$. With $\left[{ }^{3} \mathrm{H}\right] \mathrm{DNAs}$ from representatives of the genera Actinoplanes, Ampullariella, Micromonospora, Streptosporangium, Planomonospora, Kitasatoa, and Chainia, 21 of the 24 species fell into three homology clusters defined by homology values of more than $18 \%$. Values for hybridization between organisms from different clusters ranged from 4 to $15 \%$. These values were only slightly higher than the values for hybridization between any of the seven reference sporeforming Actinomycetales strains and " $M i$ - 
crococcus conglomeratus" (not on the Approved Lists of Bacterial Names [43] and not validly published since 1 January 1980; hence, without standing in nomenclature), which served as an unrelated organism with a high $\mathrm{G}+\mathrm{C}$ content (4 to $9 \%$ ). Three Actinomycetales strains could not be assigned positively to any of the three groups; these were Spirillospora albida DSM 43034, Actinomadura madurae DSM 43067, and Mi. crotetraspora viridis DSM 43175 (5 to $16 \%$ ).

Homology clusters I to III could not be defined by species of one single genus. Cluster I containing species belonging to the genera Actinoplanes and Ampullariella, as well as Amorphosporangium auranticolor DSM 43031, Dactylosporangium aurantiacum DSM 43157, and Micromonospora echinospora DSM 43141. The homology values obtained between the $\left[{ }^{3} \mathrm{H}\right] \mathrm{DNAs}$ from Actinoplanes philippinensis DSM 43019, Actinoplanes italicus DSM 43146, and Ampullariella regularis DSM 43151 and filter-bound DNAs from various species of these five genera ranged from 20 to $49 \%$.

Cluster II contained Streptosporangium roseum DSM 43021, Planomonospora parontospora DSM 43177, and Planobispora longispora DSM 43041 (homology values, 31 to $38 \%$ ), and cluster III contained Streptomyces griseus DSM 40236, Chainia antibiotica DSM 43032, Kitasatoa kauaiensis DSM 43360, Microellobosporia cinerea DSM 43033, Streptoverticillium baldaccii DSM 40845, Elytrosporangium brasiliense DSM 43159, and Actinosporangium violaceum DSM 43350 (homology values, 23 to $41 \%$ ).

DNA-rRNA reassociation studies. Nucleic acid reassociation studies between DNA and the highly conserved $23 \mathrm{~S}$ and $16 \mathrm{~S}$ rRNA's, as well as a comparative analysis of 16S rRNA's and physiological and biochemical data, have shown that organisms sharing DNA-DNA homology values of more than $20 \%$ obtained under optimal hybridization conditions can be regarded as closely related species at the genus level $(21,45$; W. Ludwig, K. H. Schleifer, G. E. Fox, E. Seewaldt, and E. Stackebrandt, J. Gen. Microbiol., in press). On the other hand, organisms with homology values below $15 \%$ cannot be generally excluded as members of one genus, as shown by studies of Staphylococcus (Ludwig et al., in press), Arthrobacter and Cellulomonas (48), and Oerskovia (45). In these investigations, organisms sharing DNA homologies of about $15 \%$ could be placed in the same genus.

To investigate the degree of relationship between the strains of the homology clusters described above and strains that were obviously not related to any of these clusters, we chose the
DNA-rRNA reassociation technique. One representative of each of the three DNA homology clusters was labeled with $\left[{ }^{3} \mathrm{H}\right]$ uracil; $16 \mathrm{~S}$ rRNA's were isolated from Actinoplanes philippinensis DSM 43019 (cluster I) and Kitasatoa kauaiensis DSM 43360 (cluster III), and 23S rRNA was isolated from Streptosporangium roseum DSM 43021 (cluster II).

Reassociation experiments were performed with various sporeforming and nonsporeforming gram-positive bacteria which had high $\mathrm{G}+\mathrm{C}$ values (more than $65 \mathrm{~mol} \%$ ) and produced mycelia, rods, and coccoids. Staphylococcus aureus ATCC 12600 was included as a gram-positive reference organism that had a low $\mathrm{G}+\mathrm{C}$ content (33 mol\%).

The 23S and 16S rRNA's of the three strains investigated were isolated by one-dimensional slab gel electrophoresis. Figure 1 shows the appearance of the two RNA bands of Streptospor. angium roseum DSM 43021. No breakdown products of either of the two RNAs were detected. However, it was important for the purity of the RNA to use log-phase cells which were disrupted and phenolized immediately after harvesting (see above). The $16 \mathrm{~S}$ rRNA isolated by this technique has been proved to be pure by fingerprinting ${ }^{32} \mathrm{P}$-labeled ribonuclease $T_{1}$-resistant oligonucleotides (Stackebrandt et al., in press).

The degree of relatedness was expressed in the following two ways: by the thermal stability of the duplexes $\left[T_{m(e)}\right]$ and by the percentage of $\left[{ }^{3} \mathrm{H}\right]$ RNA bound per $100 \mu \mathrm{g}$ of DNA (Table 2). Figure 2 shows some examples of melting curves based on 23S rRNA from Streptosporangium roseum DSM 43021.

In general, the amount of $\left[{ }^{3} \mathrm{H}\right] \mathrm{rRNA}$ that dissociates from filter-bound $\mathrm{DNA}$ at $60^{\circ} \mathrm{C}$ during

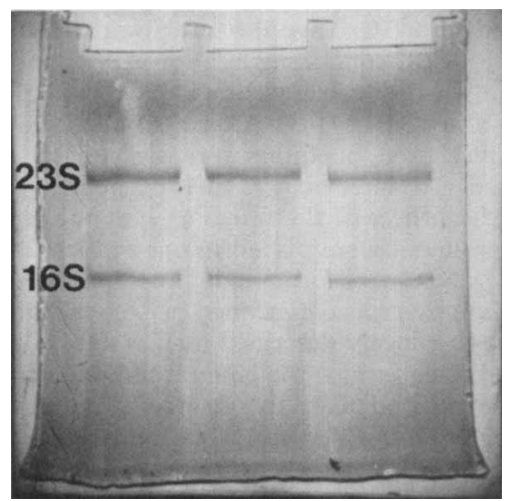

Frg. 1. Distribution of $16 S$ and $23 S$ rRNA's from Streptosporangium roseum DSM 43021 after electrophoresis on a one-dimensional sodium dodecyl sulfate-polyacrylamide slab gel. 
TABLE 2. Properties of DNA-rRNA duplexes produced with ${ }^{3} \mathrm{H}$-labeled rRNA's from Actinoplanes philippinensis DSM 43019, Streptosporangium roseum DSM 43021, and Kitasatoa kauaiensis DSM 43360 and DNAs from various sporeforming and nonsporeforming members of the Actinomycetales

\begin{tabular}{|c|c|c|c|c|c|c|c|}
\hline \multicolumn{2}{|r|}{ DNA from: } & \multicolumn{6}{|c|}{${ }^{3} \mathrm{H}$-labeled rRNA from: } \\
\hline \multirow{2}{*}{$\begin{array}{l}\text { Sequence } \\
\text { no. }{ }^{a}\end{array}$} & \multirow{2}{*}{ Strain } & \multicolumn{2}{|c|}{$\begin{array}{l}\text { Actinoplanes philip- } \\
\text { pinensis DSM } 43019\end{array}$} & \multicolumn{2}{|c|}{$\begin{array}{l}\text { Streptosporangium } \\
\text { roseum DSM } 43021\end{array}$} & \multicolumn{2}{|c|}{$\begin{array}{l}\text { Kitasatoa kauaiensis } \\
\text { DSM } 43360\end{array}$} \\
\hline & & $\begin{array}{l}\% \text { rRNA } \\
\text { binding }\end{array}$ & $\begin{array}{l}T_{m|e|} \\
\left({ }^{\circ} \mathrm{C}\right)\end{array}$ & $\begin{array}{l}\text { \% rRNA } \\
\text { binding }\end{array}$ & $\begin{array}{l}T_{\text {nule }} \\
\left({ }^{\circ} \mathrm{C}\right)\end{array}$ & $\begin{array}{l}\text { \% rRNA } \\
\text { binding }\end{array}$ & $\begin{array}{l}T_{m(t)} \\
\left({ }^{\circ} \mathrm{C}\right)\end{array}$ \\
\hline 1 & $\begin{array}{l}\text { Actinoplanes philippinensis } \\
\text { DSM } 43019\end{array}$ & 0.122 & 82.5 & 0.045 & 69.3 & 0.031 & 70.0 \\
\hline 2 & $\begin{array}{l}\text { Actinoplanes italicus DSM } \\
\quad 43146\end{array}$ & 0.091 & 77.8 & 0.051 & 72.0 & 0.033 & 71.0 \\
\hline 3 & $\begin{array}{l}\text { Ampullariella regularis DSM } \\
43151\end{array}$ & 0.090 & 78.1 & 0.064 & 69.5 & 0.060 & 70.7 \\
\hline 4 & $\begin{array}{l}\text { Ampullariella lobata DSM } \\
43150\end{array}$ & 0.098 & 78.5 & 0.082 & 72.7 & 0.054 & 71.1 \\
\hline 5 & $\begin{array}{l}\text { Ampullariella campanulata } \\
\text { DSM } 43148\end{array}$ & 0.120 & 79.2 & 0.069 & 72.7 & 0.055 & 70.9 \\
\hline 6 & $\begin{array}{l}\text { Amorphosporangium } \\
\text { auranticolor DSM } 43031\end{array}$ & 0.082 & 76.2 & 0.060 & 71.7 & 0.040 & 68.8 \\
\hline 7 & $\begin{array}{l}\text { Micromonospora echinospora } \\
\text { DSM } 43141\end{array}$ & 0.067 & 76.2 & 0.060 & 72.0 & 0.045 & 68.7 \\
\hline 8 & $\begin{array}{l}\text { Dactylosporangium } \\
\quad \text { aurantiacum DSM } 43157\end{array}$ & 0.060 & 76.4 & 0.044 & 70.5 & 0.036 & 70.3 \\
\hline 9 & $\begin{array}{l}\text { Streptosporangium roseum } \\
\text { DSM } 43021\end{array}$ & 0.080 & 72.2 & 0.125 & 82.9 & 0.044 & 71.2 \\
\hline 10 & $\begin{array}{l}\text { Planomonospora parontospora } \\
\text { DSM } 43177\end{array}$ & 0.070 & 71.0 & 0.145 & 75.3 & 0.089 & 69.7 \\
\hline 11 & $\begin{array}{l}\text { Planobispora longispora DSM } \\
43041\end{array}$ & 0.078 & 72.8 & 0.162 & 76.4 & 0.105 & 71.0 \\
\hline 12 & $\begin{array}{l}\text { Kitasatoa kauaiensis DSM } \\
\quad 43360\end{array}$ & 0.085 & 71.8 & 0.103 & 70.1 & 0.158 & 80.7 \\
\hline 13 & $\begin{array}{l}\text { Streptomyces griseus DSM } \\
\quad 40236\end{array}$ & 0.068 & 70.6 & 0.068 & 71.3 & 0.077 & 78.5 \\
\hline 14 & Chainia antibiotica DSM 43032 & 0.092 & 72.5 & 0.110 & 69.7 & 0.098 & 76.9 \\
\hline 15 & $\begin{array}{l}\text { Microellobosporia cinerea DSM } \\
43033\end{array}$ & 0.052 & 71.8 & 0.083 & 71.9 & 0.097 & 76.2 \\
\hline 16 & $\begin{array}{l}\text { Elytrosporangium brasiliense } \\
\text { DSM } 43159\end{array}$ & 0.058 & 72.8 & 0.141 & 71.8 & 0.128 & 76.8 \\
\hline \multirow[t]{12}{*}{17} & $\begin{array}{l}\text { Actinosporangium violaceum } \\
\text { DSM } 43350\end{array}$ & 0.062 & 71.0 & 0.078 & 70.5 & 0.095 & 77.9 \\
\hline & Spirillospora albida DSM 43034 & 0.068 & 71.5 & 0.101 & 71.2 & 0.067 & 67.3 \\
\hline & $\begin{array}{l}\text { Microtetraspora viridis DSM } \\
43175\end{array}$ & 0.052 & 72.1 & 0.079 & 72.7 & 0.051 & 70.4 \\
\hline & $\begin{array}{l}\text { Actinomadura madurae DSM } \\
43067\end{array}$ & 0.035 & 69.7 & 0.038 & 71.1 & 0.026 & 70.1 \\
\hline & Oerskovia turbata NCIB $10587^{b}$ & 0.040 & 72.4 & 0.030 & 70.4 & 0.041 & 70.3 \\
\hline & $\begin{array}{l}\text { Cellulomonas cartae DSM } \\
20106^{c}\end{array}$ & 0.019 & 71.6 & 0.019 & 71.0 & 0.021 & 70.6 \\
\hline & $\begin{array}{l}\text { Cellomonas flavigena DSM } \\
20109\end{array}$ & 0.048 & 71.4 & 0.044 & 71.6 & 0.047 & 71.3 \\
\hline & $\begin{array}{l}\text { "Micrococcus conglomeratus" } \\
\text { CCM } 2134^{d}\end{array}$ & 0.037 & 69.7 & 0.040 & 69.0 & 0.044 & 70.0 \\
\hline & $\begin{array}{l}\text { Micrococcus nishinomiyaensis } \\
\text { CCM } 2140\end{array}$ & 0.017 & 71.2 & 0.016 & 68.0 & 0.018 & 69.7 \\
\hline & $\begin{array}{l}\text { Micrococcus sedentarius DSM } \\
20317\end{array}$ & 0.038 & 71.2 & 0.041 & 72.0 & 0.049 & 68.2 \\
\hline & $\begin{array}{l}\text { Corynebacterium betae DSM } \\
20141\end{array}$ & 0.023 & 71.9 & 0.036 & 71.5 & 0.023 & 69.7 \\
\hline & $\begin{array}{l}\text { Microbacterium lacticum DSM } \\
\quad 20172\end{array}$ & 0.018 & 70.2 & 0.023 & 71.2 & 0.022 & 69.4 \\
\hline
\end{tabular}


TABLE 2-Continued

\begin{tabular}{|c|c|c|c|c|c|c|c|}
\hline \multicolumn{2}{|r|}{ DNA from: } & \multicolumn{6}{|c|}{${ }^{3} \mathrm{H}$-labeled rRNA from: } \\
\hline \multirow{2}{*}{$\begin{array}{l}\text { Sequence } \\
\text { no. }{ }^{a}\end{array}$} & \multirow{2}{*}{ Strain } & \multicolumn{2}{|c|}{$\begin{array}{l}\text { Actinoplanes philip- } \\
\text { pinensis DSM } 43019\end{array}$} & \multicolumn{2}{|c|}{$\begin{array}{l}\text { Streptosporangium } \\
\text { roseum DSM } 43021\end{array}$} & \multicolumn{2}{|c|}{$\begin{array}{l}\text { Kitasatoa kauaiensis } \\
\text { DSM } 43360\end{array}$} \\
\hline & & $\begin{array}{c}\text { \% rRNA } \\
\text { binding }\end{array}$ & $\begin{array}{l}T_{m(e)} \\
\left({ }^{\circ} \mathrm{C}\right)\end{array}$ & $\begin{array}{l}\text { \% rRNA } \\
\text { binding }\end{array}$ & $\begin{array}{l}T_{m(e)} \\
\left({ }^{\circ} \mathrm{C}\right)\end{array}$ & $\begin{array}{l}\% \text { rRNA } \\
\text { binding }\end{array}$ & $\begin{array}{l}T_{m(e)} \\
\left({ }^{\circ} \mathrm{C}\right)\end{array}$ \\
\hline & Agromyces ramosus DSM 43045 & 0.028 & 70.6 & 0.037 & 70.6 & 0.029 & 69.1 \\
\hline & $\begin{array}{l}\text { Arthrobacter globiformis DSM } \\
20124\end{array}$ & 0.033 & 72.5 & 0.038 & 70.9 & 0.038 & 69.3 \\
\hline & $\begin{array}{l}\text { Bifidobacterium bifidum DSM } \\
\quad 20082\end{array}$ & 0.025 & 71.2 & 0.023 & 67.0 & 0.022 & 67.3 \\
\hline & $\begin{array}{l}\text { "Bifidobacterium lactentis" } \\
\text { DSM } 20223^{d}\end{array}$ & 0.035 & 70.4 & 0.035 & 66.6 & 0.037 & 66.3 \\
\hline & $\begin{array}{l}\text { Bifidobacterium cuniculi ATCC } \\
\quad 27916\end{array}$ & 0.044 & 71.0 & 0.055 & 66.8 & 0.044 & 66.9 \\
\hline & $\begin{array}{l}\text { Staphylococcus aureus ATCC } \\
\quad 1260\end{array}$ & 0.038 & 63.8 & 0.041 & 62.2 & 0.042 & 63.0 \\
\hline
\end{tabular}

${ }^{a}$ See Fig. 3 through 5.

${ }^{b}$ NCIB, National Collection of Industrial Bacteria, Aberdeen, Scotland.

' This name is not on the Approved Lists of Bacterial Names (43), but it has been validly published since 1 January 1980 (47).

${ }^{d}$ These names are not on the Approved Lists of Bacterial Names (43) and have not been validly published since 1 January 1980; hence, they are without standing in nomenclature.

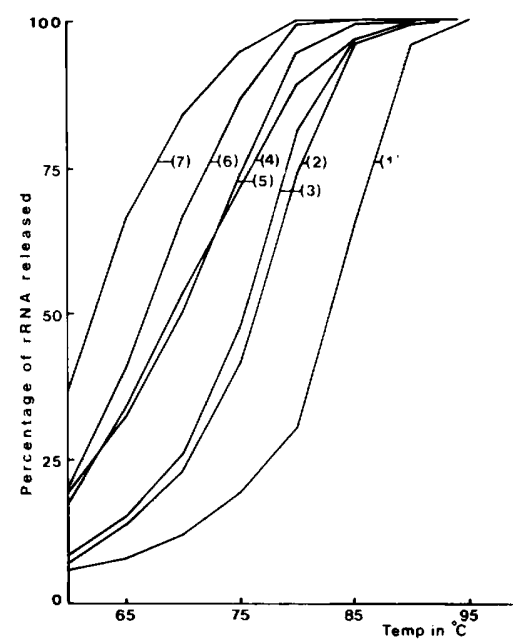

FIG. 2. Examples of melting curves of duplexes between ${ }^{3} \mathrm{H}$-labeled $23 \mathrm{~S}$ rRNA from Streptosporangium roseum DSM 43021 and DNAs from various bacteria. The counts per minute released at each temperature are expressed as percentages of the total counts released between 60 and $95^{\circ} \mathrm{C}$. Line 1, Strep. tosporangium roseum DSM 43021; line 2, Planobispora longispora DSM 43041; line 3, Planomonospora parontospora DSM 43177; line 4, Actinoplanes philippinensis DSM 43019; line 5, Kitasatoa kauaiensis DSM 43360; line 6, Bifidobacterium bifidum DSM 20082; line 7, Staphylococcus aureus ATCC 12600.

the melting process depends upon the degree of relatedness of the organisms serving as the sources of $\left[{ }^{3} \mathrm{H}\right] \mathrm{rRNA}$ and DNA $(8,21,32)$. The fact that $\left[{ }^{3} \mathrm{H}\right] \mathrm{rRNA}$ dissociates at $60^{\circ} \mathrm{C}$ is due to the conditions used to determine the $T_{m(e)}[1.5 \times$ SSC containing $20 \%$ formamide for the determination of $T_{m(e)}$ compared with $5 \times \mathrm{SSC}$ containing $25 \%$ formamide for hybridization).

Figures 3 through 5 show the correlation between $T_{m(e)}$ and rRNA binding for each reference RNA in similarity maps, as originally devised by De Smedt and De Ley (8).

As reported in previous publications on $\mathrm{RNA}$ similarities, the $T_{m(e)}$ values of the duplexes are more reliable indicators of relationships than the percentages of rRNA binding $(8,21,32)$. Closely related organisms (as determined by physiological, biochemical, and nucleic acid reassociation studies) exhibit a much smaller range in the $T_{m(e)}$ values of the duplexes than in the percentages of rRNA binding. These latter values vary with genome size and with the number of rRNA cistrons per genome (7). The $T_{m(e)}$ values of the homologous duplexes ranged from 80.7 to $82.5^{\circ} \mathrm{C}$, whereas those of the heterologous duplexes formed between the reference rRNA and DNAs from members of the same DNA homology cluster ranged from 75.3 to $79.2^{\circ} \mathrm{C}$. Neither the percentage of rRNA binding nor the $T_{m(e)}$ depended upon whether $16 \mathrm{~S}$ or $23 \mathrm{~S}$ rRNA was used as a reference. The $T_{m(e)}$ values between the reference rRNA and DNAs from members of either of the other two homology clusters were significantly lower $\left(69.3\right.$ to $\left.72.8^{\circ} \mathrm{C}\right)$. These values were similar to those obtained for representatives of Arthrobacter, Micrococcus, Cellulomonas, Oerskovia, and the plant pathogen coryneforms $\left(68\right.$ to $\left.72^{\circ} \mathrm{C}\right)$. Only the bifidobacteria showed a lower degree of rRNA similarity 


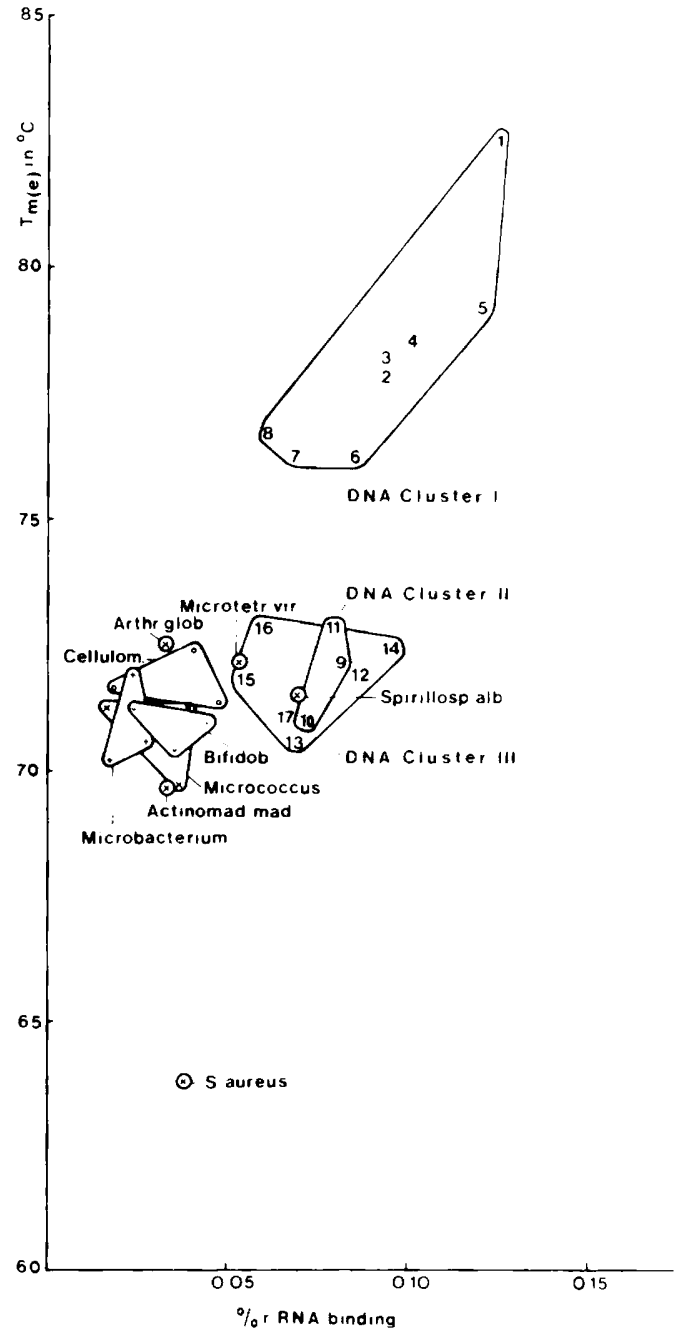

Fig. 3. Similarity map of duplexes between ${ }^{3} \mathrm{H}$-labeled 16S rRNA from Actinoplanes philippinensis DSM 43019 and DNAs from various members of the Actinomycetales. Strains belonging to DNA homology clusters $I$ through III are represented by their sequence numbers (Table 2). Nonsporeforming organisms that formed a genetic cluster as determined by DNA-DNA homology studies $(44,46)$ and comparative analyses of their 16S rRNA's (48) are marked with identical symbols. DNA homology values for bifidobacteria were obtained from E. Lauer (unpublished data), and values for Microbacterium and related organisms were obtained from $H$. Döpfer (unpublished data). Abbreviations: Actinomad. mad., Actinomadura madurae DSM 43067; Arthr. glob., Arthrobacter globiformis DSM 20124; Bifodob., Bifidobacterium (Bifidobacterium bifidum DSM 20082, Bifidobacterium lactentis DSM 20223, and Bifidobacterium cuniculi ATCC 27916); Cellulom., Cellulomonas (Cellomonas cartae DSM 20106, Cellomonas flavigena DSM 20109, and Oerskovia turbata NCIB 10587); Micrococc., Micrococcus (Micrococcus con- $\left(66.3\right.$ to $\left.71.2^{\circ} \mathrm{C}\right)$. As expected, duplexes of Staph ylococcus aureus ATCC 12600 and members of the Actinomycetales had the lowest $T_{m(e)}\left(63^{\circ} \mathrm{C}\right)$. Micromonospora echinospora DSM 43141, which shared low DNA-DNA homology with members of DNA cluster I, produced high rRNA similarity values with Actinoplanes philippinensis DSM $43019\left(76.2^{\circ} \mathrm{C}\right)$. Actinomadura madurae DSM 43067, Spirillospora albida DSM 43034, and Microtetraspora viridis DSM 43175 did not group with any of the three clusters. The $T_{m(e)}$ values for the duplexes obtained for the DNAs from these organisms and the $\left[{ }^{3} \mathrm{H}\right]-$ rRNA's from the reference organisms ranged between 67.5 and $72.7^{\circ} \mathrm{C}$.

\section{DISCUSSION}

DNA-DNA homology values of more than $20 \%$ and obtained under optimal conditions (26) have been reliable indicators of a high degree of similarity among the DNA nucleotide sequences of the strains investigated; that is, strains with such homology values have to be regarded as closely related organisms $(12,40,44,45)$. This was strikingly evident with the species included in our DNA homology cluster I. Neither in Actinoplanes nor in Ampullariella did the species group separately from the species of the other genus. Actinoplanes philippinensis and Actinoplanes italicus are as closely related to various species of Ampullariella as Ampullariella regularis is related to various species of Actinoplanes. Amorphosporangium auranticolor, Dactylosporangium aurantiacum, and Micromonospora echinospora are more distantly related, as shown by slightly lower homology values to Actinoplanes and Ampullariella. The most distinctive features separating Actinoplanes, Ampullariella, Amorphosporangium, and Dactylosporangium are the morphologies of sporangia and spores. These characteristics certainly do not carry enough genetic weight to justify a genus, but they may be appropriate for differentiation at the species level.

The genetic relatedness of Actinoplanes, Ampullariella, and Dactylosporangium has been established by Farina and Bradley (11). With $\left[{ }^{3} \mathrm{H}\right] \mathrm{DNA}$ from Actinoplanes philippinensis as a reference, Actinoplanes, Ampullariella, and Dactylosporangium could be clearly distinguished from tbe second group containing Strep-

glomeratus CCM 2134, Micrococcus nishinomiyaensis CCM 2140, and Micrococcus sedentarius DSM 20317); Microbact., Microbacterium (Microbacterium lacticum DSM 20172, Corynebacterium betae DSM 20141, and Agromyces ramosus DSM 43045); Microtetr. vir., Microtetraspora viridis DSM 43175; Spirillosp. alb., Spirillospora albida DSM 34034. 


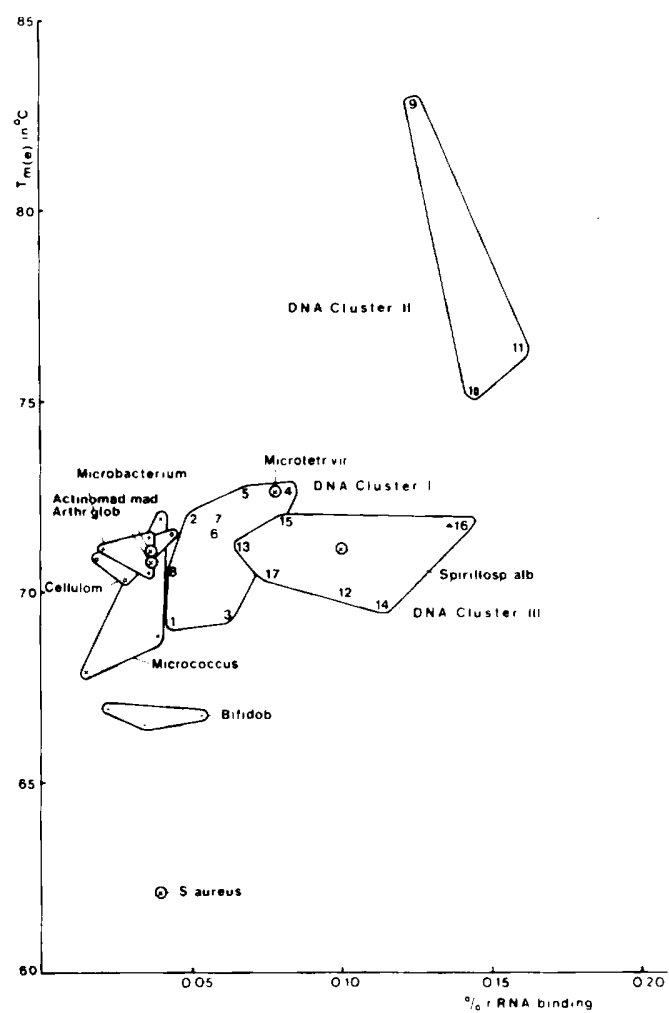

FIG. 4. Similarity map of duplexes between ${ }^{3} \mathrm{H} \cdot \mathrm{la}$. beled 23S rRNA from Streptosporangium roseum DSM 43021 and DNAs from various members of the Actinomycetales. For additional information, see leg. end to Fig. 3.

tosporangium, Spirillospora, Planomonospora, and Planobispora. In addition, we have found that Amorphosporangium and Micromonospora should be transferred to this genetically defined group. The close biochemical and physiological relationships among Micromonospora, Amorphosporangium, and the other members of this group are obvious. Although it does not form distinct spore vesicles, Micromonospora resembles Actinoplanes and its relatives in peptidoglycan type, sugar composition of the cell wall, and lack of aerial mycelia (Table 3). Furthermore, Micromonospora and Actinoplanes have been found to be specifically related in comparative physiological studies (20), as well as in comparative analyes of their 16S rRNA's (Stackebrandt et al., manuscript in preparation).

Farina and Bradley (11) concluded that those organisms which form motile spores, such as Planobispora, Planomonospora, and Spirillospora, appear to be as closely related to Streptosporangium (characterized by nonmotile spores) as they are to Actinoplanes. Because no reference DNAs of any of the former organisms were

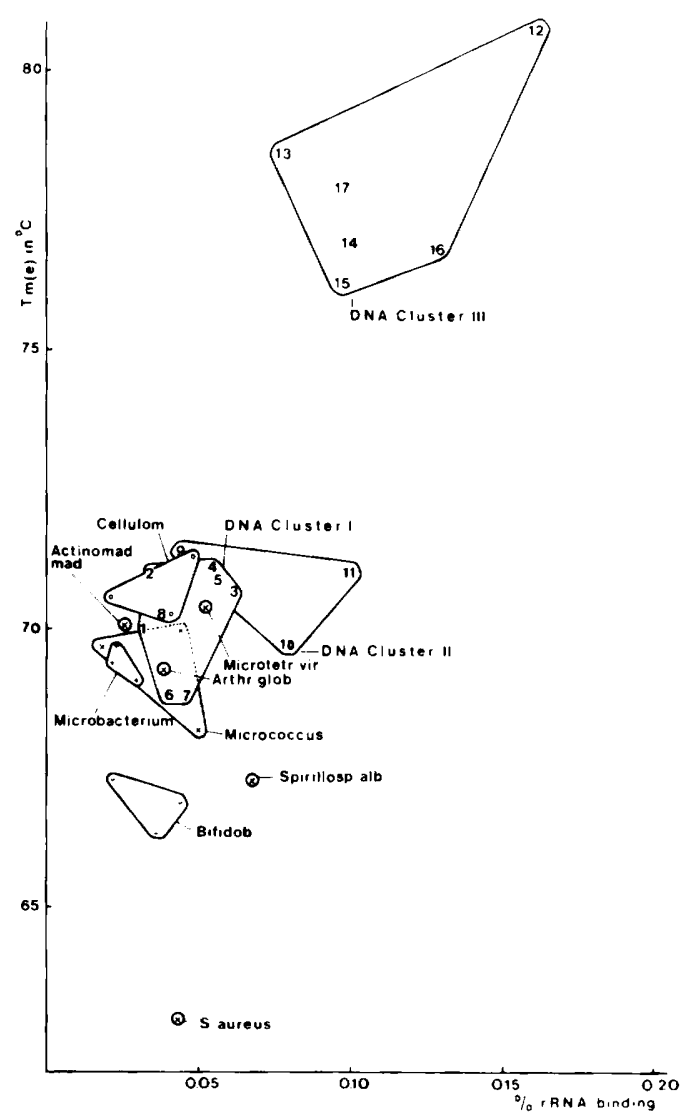

FIG. 5. Similarity map of duplexes between ${ }^{3} \mathrm{H}$-labeled 16S rRNA from Kitasatoa kauaiensis DSM 43360 and DNAs from various members of the Actinomycetales. For additional information, see legend to Fig. 3.

used in their experiments, the high degree of relatedness that actually exists among Streptosporangium, Planomonospora, and Planobispora could not be detected. However, our data show that Spirillospora albida DSM 43034 is not closely related to Streptosporangium, Planomonospora, or Planobispora despite a high degree of similarity in their biochemical and physiological features (Table 3).

The separation of streptomycetes from the sporangium-forming Actinomycetales based on morphological and biochemical criteria (Table 3) was supported by nucleic acid reassociation studies $(1,11)$, comparative physiology studies (20), phage typing experiments $(37,38)$, and comparative analyses of $16 \mathrm{~S}$ rRNA's $(13,49)$. On the other hand, there has been considerable controversy concerning the validity of the genera closely related to Streptomyces (3). Chainia, Streptoverticillium, Elytrosporangium, and Ac- 
TABLE 3. Morphological and biochemical properties of the Actinomycetales genera investigated

\begin{tabular}{|c|c|c|c|c|c|c|}
\hline \multirow[b]{2}{*}{ Genus $^{a}$} & \multirow{2}{*}{$\begin{array}{l}\text { DNA ho- } \\
\text { mology } \\
\text { cluster }\end{array}$} & \multirow[b]{2}{*}{ Peptidoglycan type ${ }^{b}$} & \multirow[b]{2}{*}{ Sugar composition } & \multicolumn{3}{|c|}{ Presence of: } \\
\hline & & & & $\begin{array}{l}\text { Aerial } \\
\text { myce- } \\
\text { lium }\end{array}$ & $\begin{array}{l}\text { Motility } \\
\text { of spores }\end{array}$ & $\begin{array}{l}\text { Sporan- } \\
\text { gia }^{c}\end{array}$ \\
\hline Actinoplanes & I & $m-\mathrm{Dpm}(+\mathrm{Gly}),^{d}(\mathrm{II})^{e}$ & Xylose, arabinose ${ }^{e}$ & $-f$ & + & + \\
\hline Ampullariella & I & $m-\mathrm{Dpm}(+\mathrm{Gly}),(\mathrm{II})^{e}$ & Xylose, arabinose $e^{e}$ & - & + & + \\
\hline Amorphosporangium & I & $m-\mathrm{Dpm}(+\mathrm{Gly}),(\mathrm{II})^{e}$ & Xylose, arabinose ${ }^{e}$ & - & + & + \\
\hline Dactylosporangium & I & $m-\mathrm{Dpm}(+\mathrm{Gly}),(\mathrm{II})^{e}$ & Xylose, arabinose ${ }^{e}$ & - & + & + \\
\hline Micromonospora & I & $m-\mathrm{Dpm}(+\mathrm{Gly}),(\mathrm{II})^{e}$ & Xylose, arabinose ${ }^{e}$ & - & - & - \\
\hline Streptosporangium & II & $m$-Dpm, $(\mathrm{A} 1 \gamma),{ }^{g}(\mathrm{III})^{e}$ & $\begin{array}{l}\text { 3-O-methyl-D- } \\
\text { galactose }^{h}\end{array}$ & + & - & + \\
\hline Planomonospora & II & $m-\operatorname{Dpm}(\mathrm{Al} \gamma),{ }^{g}(\mathrm{III})^{e}$ & $\begin{array}{l}\text { 3-O-methyl-D- } \\
\text { galactose }^{h}\end{array}$ & + & + & + \\
\hline Planobispora & II & $m-\operatorname{Dpm}(\mathrm{Al} \gamma),{ }^{g}(\mathrm{III})^{e}$ & $\begin{array}{l}\text { 3-O-methyl-D- } \\
\text { galactose }^{h}\end{array}$ & + & + & + \\
\hline Streptomyces & III & LL-Dpm-Gly, $(\mathrm{A} 3 \gamma),{ }^{g}(\mathrm{I})^{e}$ & Not characteristic ${ }^{e}$ & + & - & - \\
\hline Kitasatoa & III & LL-Dpm-Gly, $(\mathrm{A} 3 \gamma){ }^{g}(\mathrm{I})^{e}$ & Not characteristic ${ }^{e}$ & + & + & + \\
\hline Chainia & III & LL-Dpm-Gly, $(\mathrm{A} 3 \gamma),{ }^{g}(\mathrm{I})^{e}$ & Not characteristic ${ }^{e}$ & + & - & - \\
\hline Microellobosporia & III & LL-Dpm-Gly, $(\mathrm{A} 3 \gamma),^{g}(\mathrm{I})^{e}$ & Not characteristic ${ }^{e}$ & + & - & + \\
\hline Elytrosporangium & III & LL-Dpm-Gly, $(\mathrm{A} 3 \gamma){ }^{g}(\mathrm{I})^{e}$ & Not characteristic ${ }^{e}$ & + & + & - \\
\hline Streptoverticillium & III & LL-Dpm-Gly, $(\mathrm{A} 3 \gamma),{ }^{g}(\mathrm{I})^{e}$ & Not characteristic ${ }^{e}$ & + & - & - \\
\hline Actinosporangium & III & LL-Dpm-Gly, $(\mathrm{A} 3 \gamma),{ }^{g}(\mathrm{I})^{e}$ & Not characteristic ${ }^{e}$ & + & - & + \\
\hline Spirillospora & & $m-\mathrm{Dpm},(\mathrm{Al} \gamma),^{g}(\mathrm{III})^{e}$ & $\begin{array}{l}\text { 3-O-methyl-D- } \\
\text { galactose }^{h}\end{array}$ & + & + & + \\
\hline $\begin{array}{c}\text { Actinomadura ( } A . \\
\text { madurae type) }\end{array}$ & & $m-\mathrm{Dpm},(\mathrm{AI} \gamma),{ }^{g}(\mathrm{III})^{e}$ & $\begin{array}{l}\text { 3-O-methyl-D- } \\
\text { galactose }^{h}\end{array}$ & + & - & - \\
\hline Microtetraspora & & $m-\mathrm{Dpm}^{\prime}$ & Not characteristic ${ }^{j}$ & + & - & - \\
\hline
\end{tabular}

${ }^{a}$ As listed in Bergey's Manual of Determinative Bacteriology, 8th ed. (17).

${ }^{b} \mathrm{Dpm}$, Diaminopimelic acid (hydroxydiaminopimelic acid may be present in members of DNA homology cluster I [25]).

'According to Cross and Goodfellow (3).

${ }^{d}(+\mathrm{Gly}), \mathrm{L}$-Alanine is replaced by glycine in position 1 of the subunit (42).

e According to Lechevalier and Lechevalier (25).

${ }^{\prime}$ Except for Actinoplanes armeniacus.

"According to Schleifer and Kandler (42).

${ }^{h}$ According to Lechevalier and Gerber (24).

'The cell wall of Microtetraspora viridis reportedly contains meso-diaminopimelic acid, traces of LLdiaminopimelic acid, glycine, and lysine (52).

'According to Thiemann et al. (52).

tinosporangium have been regarded as synomyms of Streptomyces by some taxonomists, whereas others have favored the elevation of morphologically defined groups into genera merely to reduce the complexity of Streptomyces $(3,23)$. DNA-DNA reassociation experiments with Streptomyces venezuelae and Elytrosporangium flavea have shown that these two organisms are as closely related as Streptomyces venezuelae and other streptomycetes (1). As pointed out by Prauser (37), the broad range of S-phage activity against strains of all Streptomycetaceae genera can be taken as an indication of the high similarity of the genetic material. Our data clearly show that the separation of the members of the Streptomycetaceae into different genera on the basis of morphological criteria is unjustified; representatives of the different genera investigated here appear to be moderately related species within the genus Streptomyces. What has already been observed for the genera in DNA homology clusters I and II is also true for the Streptomycetaceae; namely, these taxa were established as a result of overclassification, which was mainly due to an overestimation of the value of morphological features.

Determinations of DNA-rRNA similarities as expressed in the average thermal stabilities of duplexes $\left[T_{m(e)}\right]$ have given no indication that the three DNA homology clusters are specifically related to one another (Fig. 6). The $T_{m(e)}$ values of DNA homology clusters I through III $\left(69\right.$ to $\left.72^{\circ} \mathrm{C}\right)$ are in the same range as those 


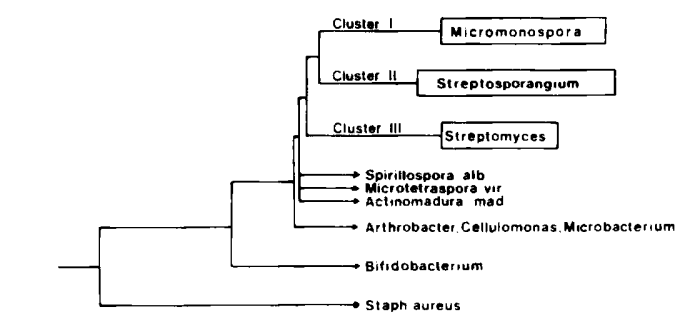
\begin{tabular}{llllll}
\hline 60 & 65 & 70 & 75 & $80 T_{\text {m(e) }}$ in ${ }^{\circ} \mathrm{C} \quad 85$
\end{tabular}

FIG. 6. Dendrogram of relationships derived from average linkage clustering of the $T_{m(e)}$ values of DNArRNA duplexes listed in Table 2. The enclosed areas represent the ranges of $T_{m(e)}$ values of the reference DNA homology clusters.

obtained for the reference rRNA and DNAs from Spirillospora albida, Microtetraspora viridis, and Actinomadura madurae, as well as from Arthrobacter globiformis, micrococci, cellulomonads, the plant pathogen coryneforms, and Microbacterium lacticum. The lower $T_{m(e)}$ values of the duplexes between the reference rRNA and DNAs from bifidobacteria caused by a higher degree of dissimilarity of the nucleotide sequences of the rRNA cistrons indicate that the bifidobacteria are more distantly related to the Actinomycetales and the coryneform bacteria.

The branching pattern shown in Fig. 6 is similar to the pattern derived from a comparative analysis of $16 \mathrm{~S}$ rRNA's $(13,49)$. Streptomyces griseus, Dactylosporangium aurantiacum, and the group of nonsporeforming Actinomycetales made up of Arthrobacter, Micrococcus, Cellulomonas, and Microbacterium share a similarity coefficient $\left(\mathrm{S}_{\mathrm{AB}}\right.$ value) of about 0.5. Members of Arthrobacter are more closely related $\left(\mathrm{S}_{\mathrm{AB}}\right.$ values, about 0.6$)$. This specific relationship is not evident in Fig. 6 because no reference rRNA of any of the bacteria was prepared for this study. On the other hand, bifidobacteria share lower $\mathrm{S}_{\mathrm{AB}}$ values with Streptomyces, Dactylosporangium, and Arthrobacter ( $\mathrm{S}_{\mathrm{AB}}$ values, 0.4). A more detailed description of the phylogeny of sporeforming Actinomycetales derived from a comparison of the oligonucleotide sequences of the 16S rRNA's will be presented elsewhere.

We are aware that the number of organisms included in this study is small compared with the large number of described species. On the other hand, the species which we investigated represent the major types of sporeforming $A C$. tinomycetales listed in Bergey's Manual, 8th ed. (17). Many more DNA-DNA reassociation studies on other species, especially on the type strains not used in our studies, will be necessary before the taxonomic rank of the three DNA homology clusters can be determined with confidence.

\section{ACKNOWLEDGMENTS}

This work was supported by the Deutsche Forschungsgemeinschaft.

We are grateful to Hannelore Döpfer and E. Lauer for providing filter-bound DNAs of microbacteria and bifidobacteria.

\section{REPRINT REQUESTS}

Address reprint requests to: Erko Stackebrandt, Lehrstuhl für Mikrobiologie, Technische Universität München, Arcisstrasse 21, 8000 München 2, Federal Republic of Germany.

\section{LITERATURE CITED}

1. Bradley, S. G., G. H. Brownell, and J. Clark. 1973 Genetic homologies among nocardiae and other actinomycetes. Can. J. Microbiol. 19:1007-1014.

2. Burton, K. 1968. Determination of DNA concentration with diphenylamine. Methods Enzymol. 12:163-166.

3. Cross, T., and M. Goodfellow. 1973. Taxonomy and classification of the actinomycetes, p. 11-112. In G Sykes and F. A. Skinner (ed.), Actinomycetales. Characteristics and practical importance. Academic Press, Inc., New York.

4. De Ley, J., and J. De Smedt. 1975. Improvements of the membrane filter method for DNA:rRNA hybridization. Antonie van Leeuwenhoek J. Microbiol. Serol. 41:287-307.

5. De Ley, J., P. Segers, and M. Gillis. 1978. Intra- and intergeneric similarities of Chromobacterium and Janthinobacterium ribosomal ribonucleic acid cistrons. Int. J. Syst. Bacteriol. 28:154-168.

6. Denhardt, D. T. 1966. A membrane-filter technique for the detection of complementary DNA. Biochem. Biophys. Res. Commun. 23:641-646.

7. De Smedt, J., M. Bauwens, R. Tytgat, and J. De Ley. 1980. Intra- and intergeneric similarities of ribosomal ribonucleic acid cistrons of free living, nitrogen-fixing bacteria. Int. J. Syst. Bacteriol, 30:106-122.

8. De Smedt, J., and J. De Ley. 1977. Intra- and intergeneric similarities of Agrobacterium ribosomal ribonucleic acid cistrons. Int. J. Syst. Bacteriol. 27:222-240.

9. Doi, R. H., and R. T. Igarashi. 1965. Conservation of ribosomal and messenger ribonucleic acid cistrons in Bacillus species. J. Bacteriol. 90:384-390.

10. Dubnau, D., J. Smith, P. Morell, and J. Marmur. 1965. Gene conservation in Bacillus species. I. Conserved genetic and nucleic acid sequence homologies. Proc. Natl. Acad. Sci. U.S.A. 54:491-498.

11. Farina, G., and S. G. Bradley. 1970. Reassociation of deoxyribonucleic acids from Actinoplanes and other Actinomycetes. J. Bacteriol. 102:30-35.

12. Fiedler, F., M. J. Schäffler, and E. Stackebrandt. 1980. Biochemical and nucleic acid hybridization studies on Brevibacterium linens and related strains. Arch. Microbiol. 129:85-93.

13. Fox, G. E., E. Stackebrandt, R. B. Hespell, J. Gibson, J. Maniloff, I. Dyer, R. S. Wolfe, W. Balch, R. Tanner, L. Magrum, L. B. Zablen, R. Blakemore, R. Gupta, K. R. Luehrsen, L. Bonen, B. J. Lewis, K. N. Chen, and C. R. Woese. 1980. The phylogeny of prokaryotes. Science 209:457-463.

14. Franklin, R. M. 1966. Purification and properties of the replicative intermediate of the RNA-bacteriophage R17. Proc. Natl. Acad. Sci. U.S.A. 55:1504-1511.

15. Gillespie, D., and S. Spiegelman. 1965. A quantitative assay for DNA-RNA hybrids with DNA immobilized on a membrane. J. Mol. Biol. 12:829-842.

16. Gillis, M., and J. De Ley. 1980. Intra- and intergenerir 
similarities of the ribosomal ribonucleic acid cistrons of Acetobacter and Gluconobacter. Int. J. Syst. Bacteriol. 30:7-27.

17. Gottlieb, D. 1974. Actinomycetales, p. 657-861. In R. E. Buchanan and N. E. Gibbons (ed.), Bergey's manual of determinative bacteriology, 8th ed. The Williams \& Wilkins Co., Baltimore.

18. Johnson, J. L., R. S. Anderson, and E. J. Ordal. 1970. Nucleic acid homologies among oxidase-negative Moraxella species. J. Bacteriol. 101:568-573.

19. Johnson, J. L., and B. S. Francis. 1975. Taxonomy of the clostridia: ribosomal ribonucleic acid homologies among the species. J. Gen. Microbiol. 88:229-244.

20. Jones, L. A., and S. G. Bradley. 1964. Relationship among streptomycetes, nocardiae mycobacteria and other actinomycetes. Mycologia 56:505-513.

21. Kilpper, R., U. Buhl, and K. H. Schleifer. 1980. Nucleic acid homology studies between Peptococcus saccharolyticus and various anaerobic and facultative anaerobic gram-positive cocci. FEMS Microbiol. Lett. 8:205-210.

22. Lapage, S. P., P. H. A. Sneath, E. F. Lessel, V. D. B. Skerman, H. P. R. Seeliger, and W. A. Clark (ed.). 1975. International code of nomenclature of bacteria. 1975 Revision. American Society for Microbiology, Washington D.C.

23. Lechevalier, H., and M. P. Lechevalier. 1967. Biology of Actinomycetales. Annu. Rev. Microbiol, 21:71-100.

24. Lechevalier, M. P., and N. N. Gerber. 1970. The identity of madurose with methyl-D-galactose. Carbohyd. Res. 13:451-454.

25. Lechevalier, M. P., and H. Lechevalier. 1970. Chemical composition as a criterion in the classification of aerobic actinomycetes. Int. J. Syst. Bacteriol. 20:435-443.

26. Marmur, J., R. Rownd, and C. L. Schildkraut. 1963 Denaturation and renaturation of DNA. Prog. Nucleic Acid Res. Mol. Biol. 1:231-300.

27. McConaughy, B. L., C. D. Laird, and B. J. McCarthy. 1969. Nucleic acid reassociation in formamide. Biochemistry 8:3289-3295.

28. Meyer, S. A., and K. H. Schleifer. 1978. Deoxyribonucleic acid reassociation in the classification of coagulasepositive staphylococci. Arch. Microbiol. 117:183-188.

29. Miller, A., U. E. Sandine, and P. R. Elliker. 1971. Deoxyribonucleic acid homology in the genus Lactobacillus. Can J. Microbiol. 17:625-634

30. Monson, A. M., S. G. Bradley, L. W. Enquist, and G. Cruces. 1969. Genetic homologies among Streptomyces violaceoruber strains. J. Bacteriol. 99:702-706.

31. Moore, R. L., and B. J. McCarthy. 1967. Comparative study of ribosomal ribonucleic acid cistrons in enterobacteria and myxobacteria. J. Bacteriol. 94:1066-1074.

32. Mordarski, M., M. Goodfellow, A. Tkacz, G. Pulverer, and K. P. Schaal. 1980. Ribosomal ribonucleic acid similarities in the classification of Rhodococcus and related taxa. J. Gen. Microbiol. 118:313-319.

33. Okanishi, M., H. Akagawa, and H. Umezawa 1972. An evaluation of taxonomic criteria in streptomycetes on the basis of deoxyribonucleic acid homology. J. Gen. Microbiol. 72:49-58.

34. Pace, B., and L. L. Campbell. 1971. Homology of ribosomal ribonucleic acid of Desulfovibrio species with Desulfovibrio vulgaris. J. Bacteriol. 106:717-719.
35. Pace, B., and L. L. Campbell. 1971. Homology of ribosomal ribonucleic acid of diverse bacterial species with Escherichia coli and Bacillus stearothermophilus. J. Bacteriol. 107:543-547.

36. Palleroni, N. J. R., R. Kunsawa, R. Contopoulou, and M. Duodoroff. 1973. Nucleic acid homologies in the genus Pseudomonas. Int. J. Syst. Bacteriol. 23:333-339.

37. Prauser, H. 1975. The Actinomycetales-an order?, p. 19-33. In Proceedings of the International Congress of IAMS, vol. 1.

38. Prauser, H. 1976. Host-phage relationships in nocardioform organisms, p. 266-284. In M. Goodfellow, G. H. Brownell, and J. A. Serrano (ed.), The biology of nocardiae. Academic Press, Inc., New York.

39. Rhuland, L. E., E. Work, R. F. Deham, and D. S. Hoare. 1955. The behavior of the isomers of $\alpha, \epsilon^{\prime}$-diaminopimelic acid on paper chromatograms. J. Am. Chem. Soc. 77:4944-4946.

40. Schleifer, K. H., W. Heise, and S. A. Meyer. 1979. Deoxyribonucleic acid hybridization studies among some micrococci. FEMS Microbiol. Lett. 6:33-36.

41. Schleifer, K. H., and O. Kandler. 1967. Zur chemischen Zusammensetzung der Zellwand der Streptokokken. I. Die Aminosäuresequenz des Mureins von Str. thermophilus und Str. faecalis. Arch. Mikrobiol. 57:335365 .

42. Schleifer, K. H., and O. Kandler. 1972. Peptidoglycan types of bacterial cell walls and their taxonomic implications. Bacteriol. Rev. 36:407-477.

43. Skerman, V. B. D., V. McGowan, and P. H. A. Sneath (ed.). 1980. Approved lists of bacterial names. Int. J. Syst. Bacteriol. 30:225-420.

44. Stackebrandt, E., and F. Fiedler. 1979. DNA-DNA homology studies among strains of Arthrobacter and Brevibacterium. Arch. Microbiol. 120:289-295.

45. Stackebrandt, E., M. Häringer, and K. H. Schleifer. 1980. Molecular genetic evidence for the transfer of Oerskovia species into the genus Cellulomonas. Arch. Microbiol. 127:179-185.

46. Stackebrandt, E., and O. Kandler. 1979. Taxonomy of the genus Cellulomonas, based on phenotypic characters and deoxyribonucleic acid-deoxyribonucleic acid homology, and proposal of seven neotype strains. Int. J. Syst. Bacteriol. 29:273-282.

47. Stackebrandt, E., and O. Kandler. 1980. Cellulomonas cartae sp. nov. Int. J. Syst. Bacteriol. 30: 186-188.

48. Stackebrandt, E., B. J. Lewis, and C. R. Woese. 1980. The phylogenetic structure of the coryneform group of bacteria. Zentralbl. Bakteriol. Parasitenkd. Infektionskr. Hyg. Abt. 1 Orig. C1:137-149.

49. Stackebrandt, E., and C. R. Woese. 1981. Towards a phylogeny of the actinomycetes and related organisms. Curr. Microbiol. 5:131-136.

50. Takahashi, H., H. Saito, and Y. Ikeda. 1967. Species specifity of the ribosomal RNA cistrons in bacteria. Biochim. Biophys. Acta 134:124-133.

51. Tewfik, E. M., and S. G. Bradley. 1967. Characterization of deoxyribonucleic acids from streptomycetes and nocardiae. J. Bacteriol. 94:1994-2000.

52. Thiemann, J. E., H. Pagani, and G. Beretta. 1968. A new genus of the Actinomycetales: Microtetraspora gen. nov. J. Gen. Microbiol. 50:295-303. 